\title{
FROM CRISIS TO MEANING: CREATIVITY IN THE BIBLICAL NARRATIVE OF EVE AND THE INVERSION BY F. KAFKA
}

\author{
Luc ANCKAERT ${ }^{1}$, Roger BURGGRAEVE ${ }^{2}$ \\ ${ }^{1}$ University of Louvain, Institute of Philosophy, Center for Ethics, Social and Political Philosophy, \\ K. Mercierplein 2, B-3000 Leuven, Belgium \\ ${ }^{2}$ University of Louvain, Faculty of Theology and Religious Studies, Department of Theological and \\ Comparative Ethics, Sint-Michielsstraat 2-4, B-3000 Leuven, Belgium
}

Received 8 May 2018; accepted 4 October 2018

\begin{abstract}
The possibilities of creativity in human life depend on discovering the meaning of life. Franz Kafka's story Before the Law evokes how every attempt at finding this meaning, represented as the law, comes with a crisis and can result in failure. The secret of human existence is all about intimate personal encounters. The other than myself, which is also deeply present inside myself, is not the impersonal thing that it is oftentimes made out to be. In an already published article, we presented a close-reading of Kafka's text. We only refer to the results in the first paragraph. In this article, we read the biblical narrative on Adam and Eve as a text that is structured by the same economy - the intertwinedness of the I-Thou relation with the I-It relation. But in opposition to the Kafka narrative, the crisis is overcome and results in a new creative perspective on the human condition: the discovery of the ultimate intersubjective meaning of life. The meaning makes love and labour possible. It means that the creativity of becoming human is the result of interaction. The context of our research is a long project on developing a philosophical reading of Biblical texts that was developed at the KU Leuven, Leuven, Belgium. The methodology is inspired by the Talmudic readings of Emmanuel Levinas and by the philosophical interpretations of the Bible of Paul Ricœur. In this way, we introduce a non-confessional way of understanding religious texts on the creativity of becoming human.
\end{abstract}

Keywords: creation narrative, dialogical thinking, human condition, Kafka, Levinas, meaning of life, Rosenzweig.

\section{Introduction: F. Kafka and Genesis}

Kafka's texts evoke in Franz Rosenzweig a very strong reminiscence of the Bible (Rosenzweig, 1979, p. 1152). Is this not an irresolvable paradox? The Bible offers stories of faith that reveal a sense, or an orientation, so that the faithful person is directed to the most important thing. Kafka, on the other hand, evokes the unceasing crisis of the forever missed opportunity. Every door that opens reveals yet a newer emptiness. In his texts, Kafka often uses "reversal" as

\footnotetext{
*Corresponding author. E-mail: luc.anckaert@kuleuven.be
} 
motif, or figure of speech. We presented the results of our close reading in a previous article (Anckaert \& Burggraeve, 2017). What follows here, is a short summary to introduce the close reading of Genesis. The parable Before the Law (in German: Vor dem Gesetz, originally published in 1916) (Kafka, 2009, pp. 154-155) can be read as just such an inversion, too, for he drops identifiably implicit hints. The text itself is followed by pseudo-Talmudic comments in which Joseph K. and the chaplain are looking for the possible meaning of the story (Kafka, 2009, pp. 155-160). The literary genre of these texts refers to the inexhaustible world of Jewish writing. In this "con-text", it is not impossible to read a reference to the first pages of the Law of Moses or Torah in the "opening paragraphs to the law" from the dialogue with the prison chaplain (Kafka, 2009, p. 154). The "opening paragraphs" could be correlated to the mythical texts from Genesis 1-11. This famous cycle of stories is the beginning or the introduction to the Torah stories about the history of God and man (Westermann, 1984). In these "opening paragraphs to the law", we read among other things the story of Adam and Eve who eat from the proscribed fruit of the forbidden tree.

The resemblances and differences are striking (see Figure 1). Instead of the restless and lonely seeker after the law, we are confronted with the archetype of the human couple. Kafka talked about the "man from the country" or the Adam ha-Aretz (literally in Hebrew "a man of the Earth" as distinct from modern usage and understanding of "a man of the world"). The place of the obstructing doorkeeper is taken by the seducing serpent. The symbolic meaning of the law is evoked by the tree of the knowledge of good and evil.

As contrasted with the parable of Kafka, Adam and Eve are confronted with the mystery of their human condition, their being created that is also an invitation for creativity. Passivity proceeds activity. Great mysteries are at stake here: the relation between liberating work and intersubjective sexuality; between freedom and sin; divinity and humanity. Entering the prohibition (the tree) does not result in the double reduction of life as in Kafka - the man from the country was murdered as a dog - but in a realistic way of human condition, marked by finitude and death (in opposition to the paradisiac condition). The confrontation with the secret of life reveals the twofold aspects of human desire: the intersubjective axis of sexuality, love and procreation and the objective axis of labour. Both aspects of creativity are

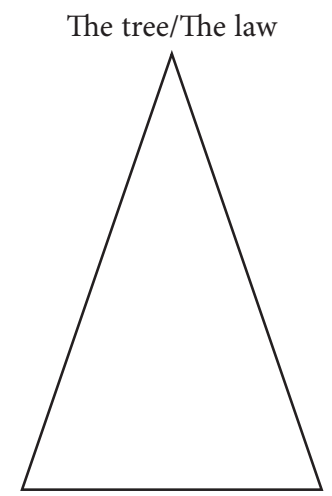

Adam (male/female)/The man from the country The serpent/The doorkeeper

Figure 1. The triangle in Kafka and Genesis (source: created by authors) 
intertwined. In her theology of creation, Dorothee Sölle connects these aspects with Sigmund Freud and Karl Marx (Sölle \& Cloyes, 1984).

The text Before the Law can be read as the inverted sense of this Biblical story. On the other hand, the mirror Kafka holds up invites reinterpretation of the light that beams from the law: "But he seems now to see an inextinguishable light begin to shine from the darkness behind the door" (2009, p. 155). The light that orients remembers the Biblical text Ps 119:105: "Your word is a lamp to my feet and a light on my path".

\section{The mystery of being created and creativity: main topic and text}

The stories in the second and third chapter of the book about the beginning ("in the beginning", Bereshit (parsha) in Hebrew) are a diptych. One of the hinged panels paints the paradisiacal life in the garden. The other evokes human life on Earth. They are stories about crisis and creativity; they offer different directions human life may take (Faessler, 2006, pp. 173174). The crisis is dramatized in the story about the tree of knowledge. We focus mainly on the extracts from the second panel, because these are inverted by Kafka, but without thereby losing sight of a number of elements from Genesis 2 in our endeavor to safeguard the reader's peripheral grasp of context, however. This interpretation of Genesis fits is a long tradition of reading biblical texts in a philosophical way, developed at the KU Leuven (Burggraeve, 2009; Anckaert, 2009). The methodology is inspired by the Talmudic readings of Levinas (Burggraeve, 2012, 2014; Wygoda, 2005) and by the philosophical interpretations of the Bible of Ricœur (LaCocque \& Ricoeur, 1998).

The story is structured along ternary dynamics. On the spot, as the restless and lonely seeker, we find the archetype of Adam (male/female), Kafka's "man from the country" - a true Adam ha-Aretz. The place of the obstructing doorkeeper is taken by a seducer, the serpent. The symbolic meaning of the law is evoked by the tree of knowledge of good and evil.

\section{Genesis 2: creativity as an answer to the task of labour and love}

4 These are the generations of the heavens and the earth when they were created, in the day that the LORD God made the earth and the heavens.

5 When no bush of the field was yet in the land and no small plant of the field had yet sprung up--for the LORD God had not caused it to rain on the land, and there was no man to work the ground,

6 and a mist was going up from the land and was watering the whole face of the ground--

7 then the LORD God formed the man of dust from the ground and breathed into his nostrils the breath of life, and the man became a living creature.

8 And the LORD God planted a garden in Eden, in the east, and there he put the man whom he had formed.

9 And out of the ground the LORD God made to spring up every tree that is pleasant to the sight and good for food. The tree of life was in the midst of the garden, and the tree of the knowledge of good and evil.

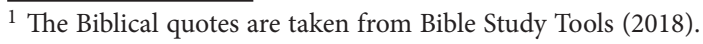


10 A river flowed out of Eden to water the garden, and there it divided and became four rivers.

11 The name of the first is the Pishon. It is the one that flowed around the whole land of Havilah, where there is gold.

12 And the gold of that land is good; bdellium and onyx stone are there.

13 The name of the second river is the Gihon. It is the one that flowed around the whole land of Cush.

14 And the name of the third river is the Tigris, which flows east of Assyria. And the fourth river is the Euphrates.

15 The LORD God took the man and put him in the garden of Eden to work it and keep it. 16 And the LORD God commanded the man, saying, "You may surely eat of every tree of the garden,

17 but of the tree of the knowledge of good and evil you shall not eat, for in the day that you eat of it you shall surely die".

18 Then the LORD God said, "It is not good that the man should be alone; I will make him a helper fit for him".

19 Now out of the ground the LORD God had formed every beast of the field and every bird of the heavens and brought them to the man to see what he would call them. And whatever the man called every living creature, that was its name.

20 The man gave names to all livestock and to the birds of the heavens and to every beast of the field. But for Adam there was not found a helper fit for him.

21 So the LORD God caused a deep sleep to fall upon the man, and while he slept took one of his ribs and closed up its place with flesh.

22 And the rib that the LORD God had taken from the man he made into a woman and brought her to the man.

23 Then the man said, "This at last is bone of my bones and flesh of my flesh; she shall be called Woman, because she was taken out of Man".

24 Therefore a man shall leave his father and his mother and hold fast to his wife, and they shall become one flesh.

25 And the man and his wife were both naked and were not ashamed.

\section{Genesis 3: creativity as living in the finite existence}

1 Now the serpent was more crafty than any other beast of the field that the LORD God had made. He said to the woman, "Did God actually say, 'You shall not eat of any tree in the garden'?"

2 And the woman said to the serpent, "We may eat of the fruit of the trees in the garden, 3 but God said, 'You shall not eat of the fruit of the tree that is in the midst of the garden, neither shall you touch it, lest you die".

4 But the serpent said to the woman, "You will not surely die.

5 For God knows that when you eat of it your eyes will be opened, and you will be like God, knowing good and evil".

6 So when the woman saw that the tree was good for food, and that it was a delight to the eyes, and that the tree was to be desired to make one wise, she took of its fruit and ate, and she also gave some to her husband who was with her, and he ate. 
7 Then the eyes of both were opened, and they knew that they were naked. And they sewed fig leaves together and made themselves loincloths.

8 And they heard the sound of the LORD God walking in the garden in the cool of the day, and the man and his wife hid themselves from the presence of the LORD God among the trees of the garden.

9 But the LORD God called to the man and said to him, "Where are you?"

10 And he said, "I heard the sound of you in the garden, and I was afraid, because I was naked, and I hid myself".

11 He said, "Who told you that you were naked? Have you eaten of the tree of which I commanded you not to eat?"

12 The man said, "The woman whom you gave to be with me, she gave me fruit of the tree, and I ate"

13 Then the LORD God said to the woman, "What is this that you have done?" The woman said, "The serpent deceived me, and I ate".

14 The LORD God said to the serpent, "Because you have done this, cursed are you above all livestock and above all beasts of the field; on your belly you shall go, and dust you shall eat all the days of your life.

15 I will put enmity between you and the woman, and between your offspring and her offspring; he shall bruise your head, and you shall bruise his heel".

$\mathbf{1 6}$ To the woman he said, "I will surely multiply your pain in childbearing; in pain you shall bring forth children. Your desire shall be for your husband, and he shall rule over you".

17 And to Adam he said, "Because you have listened to the voice of your wife and have eaten of the tree of which I commanded you, 'You shall not eat of it', cursed is the ground because of you; in pain you shall eat of it all the days of your life;

18 thorns and thistles it shall bring forth for you; and you shall eat the plants of the field.

19 By the sweat of your face you shall eat bread, till you return to the ground, for out of it you were taken; for you are dust, and to dust you shall return".

20 The man called his wife's name Eve, because she was the mother of all living.

21 And the LORD God made for Adam and for his wife garments of skins and clothed them.

22 Then the LORD God said, "Behold, the man has become like one of us in knowing good and evil. Now, lest he reach out his hand and take also of the tree of life and eat, and live forever--"

23 therefore the LORD God sent him out from the garden of Eden to work the ground from which he was taken.

24 He drove out the man, and at the east of the garden of Eden he placed the cherubim and a flaming sword that turned every way to guard the way to the tree of life.

\section{The tree as the metaphor of the creativity of labour and love}

In the stories of creation, Kafka's metaphor of the law is replaced by the tree. Contrary to the imaginary representation of unrestricted enjoyment in a dolce far niente mode, paradisiacal existence in Genesis 2 is characterized by the laws of objective labour and of intersubjective desire. Human creativity has a responsoric structure: it is the answer to the law that is being 
given to man. The first law of life gives structure to labour. Man is put in the Garden of Eden to till and to work the land:

2:15 The LORD God took the man and put him in the garden of Eden to work it and keep it.

Georg Wilhelm Friedrich Hegel (1967) pointed out that human freedom can only be realized through mediation. The immediacy of the self-willed existence is broken by the negative objectivity of labour. This externalization of freedom implies the possibility of a familial, civil, and political society. A successful life consists in the refusal of immediacy and in the gradual realization of self-identity through one's other than exclusively inside oneself (Rosenzweig, 1920a, 1920b). For this reason, Rosenzweig can interpret the created world as the social field of action. But the fundamental difference to Western ethics consists in the governess of the world to man. Man is not the origin of the world. Liberal ethics, based on economic rationality, stipulates that man is marked by an essential need or lack and that the world is a world of scarcity. Through specific rules and agreements, whether made explicit or not, it is possible to try to achieve an equitable measure of a just distribution of goods. The rules of distributive justice, institutionally mediated, seem to be utterly suited to that goal. Ethics then becomes the organization of a just society starting from scarcity (Ricœur, 1990, 1992). By contrast, the created world appears as a potential source of plenitude that is waiting for completion. It is plenitude, and not scarcity, that constitutes a structural layer of social ethics. But the created world is not only a source of plenitude. Being finite, the world is also marked by a lack. This lack constitutes an appeal to complete this world. In another vocabulary, one could speak of an ecological appeal. Since man is created and hence a part of the world, he can, by realizing his essence or intrinsic humanity, humanize the world (Anckaert, 2006, pp. 69-80).

The second founding law appears as a prohibition (Levinas, 1999, pp. 59-63). Among the trees that God allowed to grow in the Garden of Eden there was also "the tree of life in the midst of the garden, and the tree of the knowledge of good and evil" (Gn 2:9b). About this set up, God commands:

2:16 And the LORD God commanded the man, "You may freely eat of every tree of the garden; 2:17 but of the tree of the knowledge of good and evil you shall not eat, for in the day that you eat of it you shall surely die".

At the core is the prohibition to eat (Balmary, 1986, pp. 247-250). The prohibition thwarts the oral function. According to psychoanalysis, this fact is the seat of the most archaic structuring of one's personality (Thévenot, 1983, pp. 29-31). About this function the first and decisive experience of being thwarted is realized, in that the fusional (oral) relation is broken up, so that relations with "objects" other than the mother or motherly instance become possible. The distancing (indeed, severing) from the oral-osmotic unity allows for the relation with "the other". Eating means, however, the withdrawal of the difference between subject and object. By eating, the very alterity of the object is destroyed and incorporated. Eating is the symbol of the reduction of the other to the self. This is a fundamental form of violence. To know the nonviolent way, on the other hand, coincides with the ethical prohibition of cannibalism (Balmary, 1986, pp. 293-296). 
Next, the prohibition is about the tree of knowledge of good and evil. This Hebrew phrase is wider than the indication of the moral "good" and "bad"; it involves also the beautiful and the ugly; and happiness and unhappiness, too. Moreover, these words have a rather comprehensive meaning. To have knowledge of "good" and "evil" means possession of total knowledge. But in quite the same way as for Kafka, the verb "to know" (Ladaat in Hebrew) must not be reduced to merely an intellectual form of knowing: knowledge (yadah) can (and does) mean much more in Hebrew. It is more like a personal and intimate experience. The structures of knowledge reflect the physical structure of the human subject. We find a strong expression of this in Job 19:26: "and after my skin has been thus destroyed, then in my flesh I shall see God". All this suggests that the tree symbolizes the desire of omnipotence. Only if, and for as long as, the forbidding limit of the prohibition is respected can "Adam" (as "person") continue to live in Paradise.

The double law of life as the creative task of labour and the ban of omnipotence installs the ethical order, which is at the very basis of intersubjective relations. At the moment the affirmation and the prohibition are issued, there is as of yet no sign of concrete labour and intersubjectivity. It is still all about the common noun ha-Adam. Man and woman have not made their appearance yet. In other words, this is about foundational structures that will allow for human life. Levinas formulates this very clearly in his quasi-Talmudic commentary And God created Woman: "The sexual is only an accessory of the human" (1994, p. 170; Anckaert, 2009). Ethic precedes erotic: “The social [of responsibility] governs the erotic" (Levinas, 1994, pp. 168):

"Fundamental are the tasks that man accomplishes as a human being and that woman accomplishes as a human being. They have other things to do besides cooing, and, moreover, something else to do and more, than to limit themselves to the relations that are established because of the differences in sex. Sexual liberation, by itself, would not be a revolution adequate to the human species" (Levinas, 1994, p. 169).

\section{The serpent and the crisis of creativity}

In many mythical texts, the serpent functions as an archetype and it is frequently represented as the seducer (Chevalier \& Gheerbrant, 1994, pp. 867-878). In our story, it is particularly the relational meaning which is significant. The serpent introduces a crisis in the event of creativity. The serpent is said to have been more "undressed" than any other animal of the creation. In the Hebrew text, we do indeed read aroum. This is the singular form of "naked". In the previous verse, man and his wife were said to be aroumim, the dual form. The serpent symbolizes the fragile aspect of nakedness (Thévenot, 1982, pp. 44-54). Love can always be a return to oneself. When love becomes self-centred, one's other appears as a means - to an experience of lust. This level reflects the meaning of the structuring prohibition. One human becomes an edible object for another. The intended mutually balanced intersubjectivity is lost when either becomes object of/to its other. As we saw, the structuring prohibition installs an order of rank: eroticism presupposes ethics. Here, the prohibition acquires a new connotation. Knowledge is related to the way in which one treats the other. Apparently, it can be done in a "good" or a "bad" way. The good way is when one treats one's other as subject; the bad 
way is when one eats one's other as if it were an object. So knowledge is related to either a respectful or a pornographic relationship, here. Put differently, knowledge is utilized to treat one's other as either subject or object. The relationship between intersubjectivity and sheer lust can become perverted. Creativity comes to a crisis. The wriggling of the naked serpent evokes this perversion in imagery. It is serious enough, however, to be literally a matter of life and death.

\section{Man and woman, prototype of humanity}

In Gn 2, man appears as species (as ha-Adam, Man(kind), when preceded by the article ha-) in the Garden of Eden, with an order and a ban. When Man (Adam and Eve) accepts this ban and lives up to it, they live in happiness and they deal with God, who walks in the garden and speaks with them (see Gn 3:8), in a familiar way. This "state of bliss" also appears in the fact that man and wife were at first naked without being ashamed for each other:

2:25 And the man and his wife were both naked, and were not ashamed.

The shamelessness can be understood in two ways (Thévenot, 1983, pp. 38-43). Firstly, shame is the memory of the contingency of man. Gn 2:25 points out that man and his wife do not cover up or deny their sexual difference. The sexual difference confronts them with their mutual dependence, i.e., the fact that they are not omnipotent $v i s-\grave{a}$-vis each other (Levinas, 1990, pp. 34-35). This interdependence is the condition of Creation. Sexuality is the privileged place within which to experience dependence and restriction. Yet shame is also a trial. It is a self-imposed restriction against megalomania, or a delusion of grandeur in lust. But as such, it can also turn into temptation. Empty seduction by the serpent will suffice for that.

The three protagonists embody the inversion of Kafka's story: the isolated man without identity is the reversal of the connected ha-Adam (man and wife); the empty open gate is the resplendent Tree of knowledge of good and evil as intrinsic prohibition concerning life; the obstructing doorkeeper becomes the seducer qua the temptation to pervert the secret of life. In opposition to Kafka's story, Man abides with law, "becoming" (by Creation) larger as a human being, not smaller like the "man from the country".

\section{Eating the tree}

The serpent first approaches the woman (Gn 3:1b). Psychoanalysts tend to see in the serpent the symbol of the phallus (Fuchs, 1999, pp. 25-51). The phallus itself symbolizes sexual difference. Serpent as "speaking phallus" appears to the imagination of Eve precisely because it is what Adam does possess that she does not. Because Eve does not have Adam's wholly evident genital organ, she is also the first to notice the serpent and the one to be seduced. The woman, for being immersed in the problem of castration beyond her knowing, is by far more sensitive to the mirages of the imaginary. The male element is the plus sign in the sexualized world, whereas the female first appears as a hole, or a hollow, with a minus sign as to the phallus. It becomes clear in the story that the serpent - the seducer - makes the woman believe that "not having it all" means "having nothing at all". It then becomes very difficult 
for her to see the difference in meaning and to perceive what is a "lack" as something "good", especially as basis for - or access to - an equal and balanced relationship. Lack as foundation for difference opens the perspective of desire vis-à-vis the other and hence the possibility "to speak" to (or communicate, or deal with) the other (Balmary, 1993, pp. 110-122).

The serpent has genial agility and "finesse", apt to undermine the mechanisms of defence and the apparently irrefutable certainties of the longing subject in subtlest ways. The seducer is a challenger. The seducer starts his concrete job of deceit using God's original founding prohibition:

2:16 And the LORD God commanded the man, saying, "You may surely eat of every tree of the garden", except one.

The seducer tries to transform this prohibition into a proscription that restricts human freedom. The prohibition stipulated that one could eat of all trees, except for one. This prohibition is exaggerated and inverted: "Did God actually say, 'You shall not eat of any tree in the garden'?" (Gn 3:1). At this point the exegesis remarks that the Hebrew phrase is supposed to mean: "you shall not eat from any tree". Thus the seducer insinuates that God, as the Creator of desire is (by that single founding ban) the "big or total forbidder". He would not grant man his life and freedom, and would keep him always totally dependent just like a child; not a single "object" would be accessible to satisfy man's desire. In this way, the serpent stealthily instils in man's heart the first feeling of distrust in - of all things, its own Maker - God.

But the woman has seen through and somehow understood this manoeuvre very well. She reacts, making a correction: "The woman said to the serpent, 'We may eat of the fruit of the trees in the garden"' (Gn 3:2). And yet her further reaction shows how much she has been confused by the words of the serpent, all the same. She already begins to give in, by adding a few remarkable (broadening) changes to the godly ban:

3:3 but God said, "You shall not eat of the fruit of the tree that is in the midst of the garden, neither shall you touch it, lest you die".

The prohibition makes the tree more attractive; it kindles passionate desire, so that the woman does not heed the implications of life and death in the godly ban anymore. She allows herself to be fascinated or "bound" by the serpent. To the woman's reaction, which does refer to the fatal consequence of the offense, Satan (the serpent) replies by linking the wherewithal of life to the consequences of the offense: You will not surely die!". This time, taking advantage of the megalomania in man's desire, Satan adds: "for God knows that when you eat of it your eyes will be opened, and you will be like God, knowing good and evil" (Gn 3:5). As with Kafka, we rediscover the shift from believing in the Word (of the Almighty Other) to seeing as "knowing". Moreover, the seducer in the Biblical story promises that total vision, or full knowledge of good and evil, will make man "equal to God". The text is literally: "you will be like gods". Again, the imaginary omnipotence of the gods is promised. The seducer conjures up the possibility for desire to transgress contingent human condition, toward achieving superhuman (thus inhuman) pseudo-deification (Thévenot, 1983, pp. 25-49).

Fascination with omnipotence elicits a number of shifts in the woman's attitude, so that the eating becomes ultimately acceptable. First, she avoids calling the tree of knowledge of good and evil by its name. Moreover, she puts the tree in the middle of the garden. In the 
art of description, geography here becomes psychography. The prohibition begins to wield its fascinating power. All she can see now is this one single tree, right in the middle; yet she avoids naming it. She even aggravates the seriousness of the prohibition in her own eyes. Not only does she admit that God has forbidden eating from this tree, but she adds that, indeed, it is forbidden even to touch it. The tree itself has become taboo. Hence the uncontrollable desire to eat, not only from the fruit, but from the tree itself:

3:6 So when the woman saw that the tree was good for food, and that it was a delight to the eyes, and that the tree was to be desired to make one wise, she took of its fruit and ate; and she also gave some to her husband, who was with her, and he ate.

The woman gives in to the temptation and eats from the tree of the knowledge of good and evil. In so doing, she makes use of her solidarity with the man in manner to involve him in the refusal to obey God; hence, also in the self-reassuring sense of joint consent to the by now shared desire for omnipotence. In this breach of the law, the meaning of being human is revealed.

When the man from the country did not enter the law, he was murdered like a dog. This meant a double regression from humanity: the murder means the negation of life; and the bestial death, the very negation of being human. In contrast, even though Adam and Eve were told they would face death upon accessing the secret by eating, they are not killed and can live on as human beings (just as Satan had suggested), albeit with much greater difficulty in their intersubjective existence, further complicated by shattered and shattering objective reality.

\section{The consequences}

After the eating, the writer promptly points out the consequences:

3:7 Then the eyes of both were opened, and they knew that they were naked; and they sewed fig leaves together and made loincloths for themselves.

The discovery of the secret, concealed in the law, is neither a revelation of good and evil nor a realization of the desire of omnipotence, or acquaintance with all godly, worldly, and human secrets; it is the confrontation with nakedness. Instead of realizing the human phantasms of godly omniscience and divine omnipotence, man discovers his own contingency now all too evident in the sheer impossibility of his realizing the false promises of the imaginary. The disappointment that the grave offense produces "opens the eyes" for the real and concrete differences that characterize both the human condition and mankind's finite existence. The meaning and implications of the "discovery" of nakedness by way of a newly acquired awareness contrasts with the shameproof acquiescence of nakedness-as-fact that the story opened with. Being aware of his own nakedness in the eyes of the opposite sex, now also man is confronted with the issue of sexual difference. What externally even more directly appears as bodily difference also signals and implies the relationship the human condition entertains with difference and otherness (alterity) as such. In this relationship, man experiences his own existence as, both, restricted and finite. 
The awareness of one's "naked" finiteness, namely the discovery of the ultimate human secret, is experienced concretely in the seemingly paradoxical human condition that reconciles potentially uniting love and putatively alienating labour; two aspects shared by man and woman who are divided differently by either of these activities in the framework of an existential condition common to both:

3:16 To the woman he said, "I will surely multiply your pain in childbearing; in pain you shall bring forth children. Your desire shall be for your husband, and he shall rule over you".

Here the Jawhist Biblical author describes the woman in realistic context - that of 10th century society (Lebrun \& Wénin, 2008, pp. 180-224). She is reduced to an ambiguous relationship with her children whom she will have to bear in great pain and labour. Moreover, she lives with her husband in a relationship of desire and temptation under phallocratic supremacy. The Biblical author goes on to paint a painful picture of the way in which the intersubjective relationship between man and woman is actually experienced in a masterslave relationship: the woman is stuck in a dramatic deadlock, in which she is and remains the victim of socially sanctioned androcracy. Her desire, which reaches out to her husband, is abused by him the better to subdue her. Owing to this tragic situation, the woman attains a diabolical state of submission and supremacy. Become a slave to the power of physical attraction, she is now at a tyrant's mercy.

The whole Old Testament is well aware of this violence, which originates from the "unordered" sexuality that does not respect either difference or alterity (LaCocque \& Ricœur, 1998, pp. 157-189). Phallocratic sexuality can lead to extremes of deadly violence, as is the case for example in the story found in Judges 19-21. The sexual violence by the inhabitants of Gibeah to the wife of the Levite from Efraim leads to her death (Ju. 19:22-26). This violence is not restricted to intersubjective relationship, however; it affects the whole community. A collective kind of violence arises that brings with it almost the total destruction of the tribe of Benjamin (Ju. 20:8-47). The most holy laws of hospitality, heterosexuality, and respect for a neighbour's wife were violated in one concrete form of violence. The whole society was affected. And yet this tragedy is not fatal. In spite of the potential perversion of desire, woman is acknowledged by man as mother, as a fundamental element in mankind's life on earth. Once again, woman becomes linked to the godly act of creation:

3:20 The man named his wife Eve, because she was the mother of all living. 4:1 Now the man knew his wife Eve, and she conceived and bore Cain, saying, "I have produced a man with the help of the LORD".

Procreation is not only the restoration of the fusional unity between man and woman, but finds its truth in the child that opens the future. This is apparent from a reading of Rashi (Unknown Year) ${ }^{2}$ in Genesis 2:

2:24 Therefore a man leaves his father and his mother and hold fast to his wife, and they shall become one flesh.

\footnotetext{
2 Shlomo Yitzchaki, known by the acronym Rashi (Rabbi Shlomo Y-itzchaki), was born 22 February, 1040 and died 13 July, 1105; a medieval French Rabbi, he authored the first comprehensive commentary on the Talmud, as well as a comprehensive commentary on the Tanakh (the Hebrew Bible).
} 
This verse is often read as the indication that the sexual coitus - the act of becoming one flesh - is an emotional-physical experience that overcomes the duality of man and woman. The sexual coitus would mean a cosmic recovery of the lost unity of man and woman. This interpretation is compatible with the androgynous myth by Aristophanes, narrated by Plato in his Symposium (Plato, 2001, pp. 189a-191b). The interpretation became a classic topos in Jewish philosophy by its integration in the third of the Dialoghi d'amore of Judah Leon Abravanel (Ebreo, 1929). Love brings together again the two split halves of what was once one indivisible entity, whereby a return to one's original self follows. What this suggest implicitly is a cyclical concept of time: paradisiacal unity $->$ separation $->$ restoration. Rashi, however, comments the verse as follows: "The child is shaped by both of them, and that [i.e. in the child] is where their body becomes one". Rashi prefers the model of the ever renewed future where, in the interpersonal encounter, an unpredictable new man and a new world can always come into being again and again. By comparison, for being neither created nor procreative, sexuality is narcissistic; directed to the only future it knows of - a self-perpetuating one (Balmary, 1986, pp. 188-189).

A punitive condition related to the breached objective labour relation is allocated to man:

3:17 And to the man he said, "Because you have listened to the voice of your wife, and have eaten of the tree off which I commanded you, 'You shall not eat of it', cursed is the ground because of you; in pain you shall eat of it all the days of your life"; 3:18 thorns and thistles it shall bring forth for you; and you shall eat the plants of the field. 3:19 By the sweat of your face you shall eat bread, till you return to the ground, for out of it you were taken; you are dust, and to dust you shall return.

Once again, the Biblical author/redactor rationalizes the situation of the man in his contemporary Jewish society (Bieringer, 2014), here, by relating his narrative to the culturalhistorical situation on the ground. The labour relation is not always a relation of self-development and wealth; rather, it is often characterized by forms of alienation. This alienation is the result of human self-insufficiency, with no bearing on any desire of omnipotence. But it is not owing to the infringement of the fundamental Order of Creation that man is summoned to work. Labour, originally, is neither punishment nor burden; it is actually a blessing: 2:15 The LORD God took the man and put him in the Garden of Eden to till it and keep it.

Eventually, however, in the same way as woman will come to face the violence of man, man will have to face battle with the land - violently. Both man and woman can become alienated in their daily fate. Woman is mother; but she also is her husband's slave. Man is unhappy producer but also father and husband. Yet these relations, even when perverted, do not mean the destruction of the Order of Creation. Perversion may mean possible inversion of the Order, but this is not necessarily preordained fate. These relations may change; they may develop differently. This may well be the reason why the consequences of the discovery of the law did not lead to death in Paradise, but to life on Earth, in its concrete reality (Basset, 2007, pp. 61-77). Upon entering concrete life on Earth as a contingent being, Paradise is forever left behind. Outside of Paradise, man and woman live on, their children are born; and, as a promise of the future, it is these children that perform the first forms of labour:

3:23 therefore the LORD God sent him forth from the Garden of Eden to work the ground from which he was taken. 3:24 He drove out the man; and at the east of the garden of Eden he placed the cherubim and a flaming sword that turned every way 
to guard the way to the tree of life. 4:1 Now the man knew his wife Eve, and she conceived and bore Cain, saying, "I have produced a man with the help of the LORD". 4:2 Next she bore his brother Abel. Now Abel was a keeper of sheep, and Cain a tiller of the ground.

\section{Conclusions}

Kafka's parable and the creation narrative deal with the possibility of human creativity. For Kafka, the possibilities of life were locked by the impossibility of the intersubjective relation in which the secret can be revealed. In contrast to Kafka's parable, Adam and Eve do enter the confrontation with the secret of their creation. Great things are at stake here: liberating labour alongside subjugating sexuality, the relationship between freedom and sin, the combination of divinity and humanity. This confrontation cannot but take place by critical offense. A crisis (krinein) arises: a break with the obvious and the evident. Real creativity is not a solipsistic adventure or a makeable ideal, but the confrontation with alterity. Thereby the introduction of "the different" occurs: the very difference of "the other" emerges and materializes. Suddenly, the paradisiacal rest is at stake.

Entering this prohibition does not lead, however, to a double reversal from humanity, namely dying (and dying like a dog) as in Kafka, but to a creative, realistic human capacity for meaning, characterized by finiteness and struggle, and death (versus a paradisiacal condition of eternal if blessedly ignorant bliss). Upon its confrontation with the secret of life, from its Biblical outset, human capacity for meaning is, as it were, shaped in two fundamental aspects of desire: the intersubjective axis (sexuality, love, and procreation) and the objective axis (labour). The bestowal of creativity to human desire is only achieved by the critical mediation of, and confrontation with, the law - namely, the very expression of otherness that provokes newer meaning, through a crisis of the self (Ausloos \& Lemmelijn, 2016).

\section{References}

Anckaert, L. A. (2006). A critique of infinity: Rosenzweig and Levinas. Series: Studies in Philosophical Theology. Leuven, Paris, Dudley, MA: Peeters.

Anckaert, L. (2009). L'Être Entre les Lettres. Creation and Passivity in "And God Created Woman". In B. Hofmeyr (Ed.), Radical passivity: rethinking ethical agency in Levinas. Series: Library of Ethics and Applied Philosophy. Vol. 20 (pp. 143-154). Dordrecht: Springer Science + Business Media B.V.

Anckaert, L., \& Burggraeve, R. (2017). Crisis and meaning: F. Kafka and the Law. Coactivity: Philosophy, Communication, 25, 123-144.

Ausloos, H., \& Lemmelijn, B. (2016). La Bible et la vie: Réponses bibliques aux questions d'aujourd'hui, 1(48). Series: Le livre et le rouleau. Namur, Paris: Lessius.

Balmary, M. (1993). La Divine Origine: Dieu nia pas créé l'homme. Paris: Éditions Grasset \& Fasquelle. Balmary, M. (1986). Le Sacrifice interdit: Freud et la Bible. Paris: Éditions Grasset \& Fasquelle.

Basset, L. (2007). Holy anger: Jacob, Job, Jesus. London: Continuum.

Bible Study Tools. (2018). English standard version. Retrieved from https://www.biblestudytools.com/esv/

Bieringer, R. (2014). Body and Bible: Biblical revelation as a symbolic event. In R. Bieringer, R. Burggraeve, E. Nathan, \& M. Steegen (Eds.), Provoked to speech: Biblical hermeneutics as conversation (pp. 315-342). Leuven-Paris-Walpole (MA): Peeters. 
Burggraeve, R. (2012). A true master of thought - taking the Talmudic philosophy of Levinas as an inspiration for Christianity. In R. Burggraeve, J. Hansel, M.-A. Lescourret, J.-F. Rey, J.-M. Salanskis (Eds.), Recherches Levinassiennes (pp. 399-419). Louvain-la-Neuve/Louvain-Paris: Peeters Publishers.

Burggraeve, R. (2009). Each other's keeper? Essays on ethics and the Biblical wisdom of love. Thrissur: Marymatha Publications.

Burggraeve, R. (2014). Reading and interpreting holy scripture: a way of thinking. In R. Bieringer, R. Burggraeve, E. Nathan, \& M. Steegen (Eds.), Provoked to speech: Biblical hermeneutics as conversation (pp. 85-108). Leuven-Paris-Walpole, MA: Peeters Publishers.

Chevalier, J., \& Gheerbrant, A. (1994). Dictionnaire des Symboles: Mythes, rêves, coutumes, gestes, formes, figures, couleurs, nombres. Paris: Robert Laffont.

Faessler, M. (2006). Éclats: Quand Levinas commente Rachi. In D. Cohen-Levinas (Ed.), Levinas (pp. 173-192). Paris: Bayard.

Fuchs, É. (1999). Le Désir et la tendresse: pour une éthique chrétienne de la sexualité. Paris/Genève: Albin Michel/Labor et Fides.

Hegel, G. W. F. (1967). Philosophy of right. London, New York: Oxford University Press.

Kafka, F. (2009). The trial. J. B. Kopito (Ed.). Series: Dover Thrift Editions. Waldrep, M. C. (General Ed.). Mineola, NY: Dover Publications.

LaCocque, A., \& Ricœur, P. (1998). Penser la Bible. Paris: Éditions du Seuil. https://doi.org/10.14375/NP.9782020316774

Lebrun, J.-P., \& Wénin, A. (2008). Des lois pour être humain. Series: Humus Entretiens. Toulouse: Éres. Ebreo, L. (1929). Dialoghi d'amore. Hebräische Gedichte. Heidelberg: Winter.

Levinas, E. (1990). Difficult freedom: essays on Judaism. Baltimore: John Hopkins University Press.

Levinas, E. (1999). New Talmudic readings. Pittsburgh: Duquesne University Press.

Levinas, E. (1994). Nine Talmudic readings. Bloomington and Indianapolis: Indiana University Press.

Plato. (2001). Lysis. Symposium. Gorgias. Series: Loeb Classical Library. Cambridge (Mass.): Harvard University Press.

Rashi. (unknown year). Pentateuch with Targum Onkelos, Haphtaroth and Rashi's Commentary. Genesis. New York: Hebrew Publishing Company.

Ricœur, P. (1990). Liebe und Gerechtigkeit = Amour et justice. Tübingen: J. C. B. Mohr (P. Siebeck).

Ricoeur, P. (1992). Oneself as another. Chicago and London: The University of Chicago Press.

Rosenzweig, F. (1979). Der Mensch und sein Werk Gesammelte Schriften. Bd. 1: Briefe und Tagebücher, 1900-1918. R. Rosenzweig \& E. Rosenzweig-Scheinmann (Eds.). Dordrecht: Springer Science+Business Media. https://doi.org/10.1007/978-94-017-0958-3

Rosenzweig, F. (1920a). Hegel und der Staat. Bd. I: Lebensstationen (1770-1806). München-Berlin: Oldenburg.

Rosenzweig, F. (1920b). Hegel und der Staat. Bd. II: Weltepochen (1806-1831). München-Berlin: Oldenburg.

Sölle, D., \& Cloyes, Sh. A. (1984). To work and to love: a theology of creation. Minneapolis: Augsburg Fortress Publishing House.

Thévenot, X. (1983). Les péchés. Que peut-on en dire?. Mulhouse: Salvator.

Thévenot, X. (1982). Repères éthiques pour un monde nouveau. Mulhouse: Salvator.

Westermann, C. (1984). Genesis 1-11: a continental commentary. London, Minneapolis: SPCK, Augsburg Publishing House.

Wygoda, Sh. (2005). Un Midrash philosophique. À propos de la lecture levinassienne du Talmud. Cahiers d'Etudes Lévinassiennes, 4, 313-352. 


\title{
NUO KRIZĖS LINK PRASMĖS: KŪRYBIŠKUMAS BIBLINIAME NARATYVE APIE IEVĄ IR F. KAFKOS APVERTIMAS
}

\author{
Luc ANCKAERT, Roger BURGGRAEVE
}

\section{Santrauka}

Kūrybiškumo galimybès žmogaus gyvenime priklauso nuo atrastos gyvenimo prasmès. Franzo Kafkos apysaka Prieš įstatyma sukelia minčių, kaip bet kokiomis pastangomis rasti šią įstatymo simbolizuojamą prasmę, prasidedančią nuo krizès ir galinčią baigtis nesèkme. Žmogaus egzistavimo paslaptis yra absoliučiai neatsiejama nuo intymių asmeniniu sutikčių. Kitas, skirtingai nei aš pats, kuris taip pat esti giliai manyje pačiame, nèra nesuasmenintas daiktas, kuris dažnai taip traktuojamas. Jau paskelbtame straipsnyje pristateme nuodugnų Kafkos teksto aiškinimą. Pirmame skirsnyje tiesiog pateikiame prieitas išvadas. Šiame straipsnyje interpretuojame biblinị Adomo ir Ievos naratyvą kaip tekstą, kurio struktūra grindžiama tokia pat ekonomija - Aš-Tu ir Aš-Tai santykio sampyna. Tačiau, priešingai Kafkos naratyvui, krizė ịveikiama ir baigiasi nauja kūrybine žmogaus būklès perspektyva, atradus didžiausią intersubjektyvią gyvenimo prasmę. Prasmè suteikia galimybę mylèti ir dirbti. Tai reiškia, kad tapimo žmogumi kūrybiškumas yra sąveikavimo rezultatas. Mūsų tyrimo kontekstą sudaro Leveno katalikiškajame universitete (Levenas, Belgija) vykdytas ilgalaikis projektas, plètojęs filosofines biblinių tekstų interpretacijas. Šiuo atveju pristatome nekonfesinį būdą suprasti religinius tekstus, skirtus tapimo žmogumi kūrybiškumui.

Reikšminiai žodžiai: kūrimo naratyvas, dialoginis mąstymas, žmogaus būklè, Kafka, Levinas, gyvenimo prasmè, Rosenzweigas. 